[Regular Paper]

\title{
Synthesis of Cyclopentyl Methyl Ether by Gas Phase Catalytic Reaction Using Strong Acid lon Exchange Resin as a Catalyst - Study of Catalyst Deactivation Mechanism-
}

\author{
Hideaki MIKI* \\ Research and Development Center, Zeon Corp., 1-2-1 Yako, Kawasaki-ku, Kawasaki 210-9507, JAPAN
}

(Received November 21, 2018)

\begin{abstract}
Catalyst life was studied for developing a process for producing cyclopentyl methyl ether by continuous gas phase addition of cyclopentene and methanol using a strongly acidic ion exchange resin as a catalyst. Activity of the catalyst was found to decrease with time. C5 diolefins were indicated to form deactivation factor substances by analysis of substances deposited on the spent catalyst, analysis of behaviors of trace impurities before and after reaction, and other findings. Catalyst lifetime test using feedstock containing no C5 diolefins showed that deactivation of catalytic activity was greatly suppressed. The mechanism of catalyst deactivation is discussed based on the results of experiments reproducing tar formation, accelerated deactivation visualizing the inside of the reaction tube, and others.
\end{abstract}

\section{Keywords}

Acidic ion exchange resin, Cyclopentyl methyl ether, Gas phase catalytic reaction, Deactivation

\section{Introduction}

Ethers are widely used in the chemical industry as solvents for fine organic synthesis and polymerization reactions, intermediates for organic synthesis, paint removers and similar purposes in large amounts. Diethyl ether and tetrahydrofuran (THF) are very typical ethers used for these various purposes. In particular, diethyl ether is commonly used as a solvent for fine organic synthesis under anhydrous conditions such as the Grignard synthesis. THF is mainly used as a polymerization solvent and as an aprotic polar solvent for fine organic synthesis(1),2). However, these ethers present various problems in handling. The very low boiling point and flash point of diethyl ether require very careful handling to avoid accidents like explosions and fires, especially during purification, usually by distillation. THF is freely miscible with water, so cannot be used as an extraction agent. Furthermore, THF is easily converted to its peroxide, which decomposes very easily and may cause explosions and fires.

Cyclopentyl methyl ether (CPME) is an entirely new type of ether, developed primarily as a solvent for fine organic synthesis. Unlike THF, CPME has excellent energy-saving and safety characteristics including easy separation and recovery from water, low latent heat of

DOI: doi.org/10.1627/jpi.62.173

*E-mail: H.Miki@zeon.co.jp vaporization, and negligible generation of peroxide. Therefore, CPME is an environmentally friendly solvent and is suitable for university or college teaching from the viewpoint of ensuring student safety. The differences in physical properties between CPME and other common ethers are shown in Table $\mathbf{1}^{3}$.

CPME has various characteristics common with general-purpose ethers, which can be handled very safely, so is widely used as a solvent for alkylation, silylation, organometallic reaction, Grignard reaction, enantiomer selective reaction, reduction, polymerization, etc. ${ }^{4) \sim 10)}$. CPME is manufactured by a synthetic method from cyclopentanol (CPL) as a starting material (Scheme 1).

CPL is produced by hydrogenation of cyclopentanone, a 5-membered ring ketone. In addition, equimolar amounts of by-product $\mathrm{NaI}$ are produced as waste, which requires water-washing procedure for separation from CPME. Therefore, the process is expensive and not environmentally appropriate. In addition, this reaction is carried out by a batch method, so a large scale batch reactor is necessary for mass production, as well as much other equipment related to processes other than the reactor. Increased production to satisfy demand surpassing the predetermined production capacity may be difficult to achieve because of the need for re-installation of the equipment including auxiliary equipment other than the main reactor. For these reasons, production of CPME by the reaction in Scheme $\mathbf{1}$ is economically unfeasible. Therefore, the authors devised a produc- 
Table 1 Comparison of Physical Properties of CPME and Other Ethers

\begin{tabular}{|c|c|c|c|c|}
\hline Ethers & & $\begin{array}{l}\text { Cyclopentyl methyl ether } \\
\text { (CMPE) }\end{array}$ & $\begin{array}{l}\text { Tetrahydrofuran } \\
\text { (THF) }\end{array}$ & Diethyl ether \\
\hline Chemical structure & & $\mathrm{OMe}$ & & \\
\hline Density $\left(20^{\circ} \mathrm{C}\right)$ & {$\left[\mathrm{g} \mathrm{cm}^{-3}\right]$} & 0.86 & 0.89 & 0.71 \\
\hline Vapor specific gravity (air = 1) & {$[-]$} & 3.45 & 2.49 & 2.56 \\
\hline Boiling point & {$\left[{ }^{\circ} \mathrm{C}\right]$} & 106 & 65 & 34.6 \\
\hline Heat of vaporization (at boiling point) & {$\left[\mathrm{kJ} \mathrm{kg}^{-1}\right]$} & 289.7 & 410.7 & 360.5 \\
\hline Solubility in water $\left(23^{\circ} \mathrm{C}\right)$ & {$\left[\mathrm{g} 100 \mathrm{~g}^{-1}\right]$} & 1.1 & $\infty$ & 6.5 \\
\hline Water solubility in ether $\left(23^{\circ} \mathrm{C}\right)$ & {$\left[\mathrm{g} 100 \mathrm{~g}^{-1}\right]$} & 0.3 & $\infty$ & 1.2 \\
\hline Flash point & {$\left[{ }^{\circ} \mathrm{C}\right]$} & -1 & -14.5 & -45 \\
\hline
\end{tabular}<smiles>OC1CCCCC1</smiles>

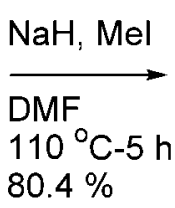<smiles>COC1CCCC1</smiles>

Scheme 1

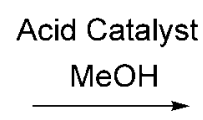

$$
\widehat{C P E}
$$

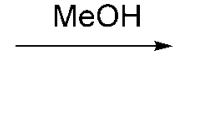

Scheme 2

tion method using the addition of methanol $(\mathrm{MeOH})$ to cyclopentene (CPE) as illustrated in Scheme $\mathbf{2}$ for the development of a manufacturing process suitable for mass production $^{11)}$.

This method uses only $\mathrm{CPE}, \mathrm{MeOH}$ and acid catalyst as raw materials. Since the reaction is also quite simple, the process can be performed in a flow system, and the scale of the reactor can be greatly reduced in comparison with the batch method, if solid acid catalyst can be applied. Suitable solid acid catalysts include oxide type catalyst such as $\mathrm{Al}_{2} \mathrm{O}_{3}$, mixed oxide type catalyst such as $\mathrm{SiO}_{2} / \mathrm{Al}_{2} \mathrm{O}_{3}$, zeolite type catalyst such as H-ZSM-5, and strong acid cation exchange resin. Strong acid cation exchange resin is an excellent solid acid in terms of acid strength and acid density, and is widely used for water purification, and other process$\mathrm{es}^{12) \sim 19)}$. All these processes are operated in the liquid phase. Liquid phase operation is common in a region where the load of raw material (flow rate of the raw material) is relatively small to prevent disturbance of the packed bed. On the other hand, if a strongly acidic ion exchange resin can be applied to the gas phase reaction, the pressure drop of the catalyst bed can be greatly reduced. Consequently, the load of the raw materials

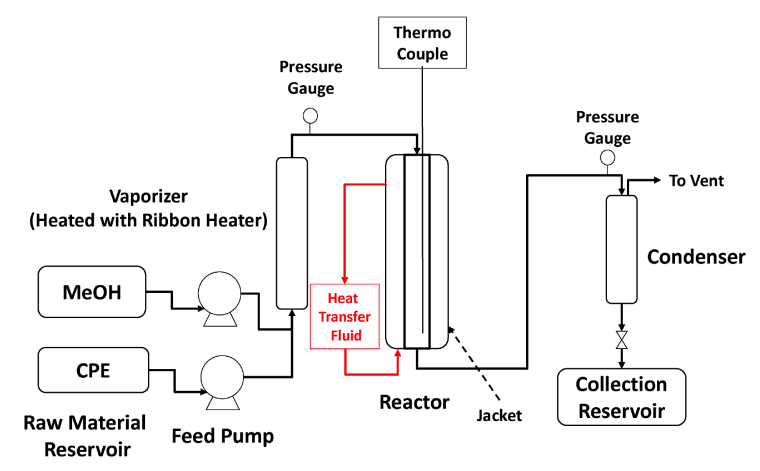

Fig. 1 Schematic Drawing of Lab Scale Reactor for Catalyst Life Test

Table 2 Reaction Conditions of Life Test Using Lab Scale Reactor

\begin{tabular}{lc}
\hline Feed content & $\mathrm{CPE} / \mathrm{MeOH}=1 / 0.63$ by mol \\
& $(\mathrm{CPE} / \mathrm{MeOH}=1 / 0.30$ by wt $)$ \\
Bed length (dry base) & $285 \mathrm{~mm}$ \\
Tube inner diameter & $27.2 \mathrm{~mm}$ \\
GHSV & $151 \mathrm{~h}^{-1}$ \\
Outlet pressure & $0.0 \mathrm{MPaG}$ \\
HTF temperature & $90{ }^{\circ} \mathrm{C}$ \\
\hline
\end{tabular}

on the catalyst can be increased to minimize the size of the reactor.

\section{Experimental}

\section{1. Catalyst Life Test}

Catalyst performance was evaluated using a laboratory scale fixed bed continuous flow type reaction system. The catalyst was a strongly acidic ion exchange resin (RCP-160 M, Mitsubishi Chemical Corp.). CPE (Zeon Corp. $\geqq 95 \mathrm{GC} \%$ ) and $\mathrm{MeOH}$ (Mitsubishi Gas Chemical Co., Inc. $\geqq 99$ GC\%) were used as feedstocks, with purity confirmed within the specification by gas chromatography. The outline flow of the reaction system is described in Fig. 1, and the reaction conditions are shown in Table 2.

Predetermined amounts of $\mathrm{CPE}$ and $\mathrm{MeOH}$ were 
introduced into a vaporizer with separate feed pumps, then introduced into the reactor. The effluent gas from the reactor was condensed, followed by collection and analysis of the effluent by gas chromatography to determine the composition. In addition, to determine the feed rate of the raw material and the effluent flow rate, the masses of consumed raw material and condensed effluent were periodically measured to calculate the mass balance. The reaction results were calculated by the following formulae.

$\mathrm{CPE}$ conversion $(\mathrm{mol} \%)=$

$\frac{(\text { Feed rate of CPE }(\mathrm{mol} / \mathrm{min})-\text { Outlet flow rate of } \mathrm{CPE}(\mathrm{mol} / \mathrm{min}))}{\text { Feed rate of } \mathrm{CPE}(\mathrm{mol} / \mathrm{min})} \times 100$

CPME yield $(\mathrm{mol} \%)=$

$\frac{\text { Outlet flow rate of CPME }(\mathrm{mol} / \mathrm{min})}{\text { Feed rate of CPE }(\mathrm{mol} / \mathrm{min})} \times 100$

CPME selectivity $(\mathrm{mol} \%)=\frac{\mathrm{CPME} \text { yield }(\mathrm{mol} \%)}{\mathrm{CPE} \text { conversion }(\mathrm{mol} \%)} \times 100$

Relative activity $(-)=$

Measured CPE conversion ( $\mathrm{mol} \%)$

Initial CPE conversion ( $\mathrm{mol} \%)$

Relative selectivity $(-)=$

Measured CPME selectivity (mol\%)

Initial CPME selectivity $(\mathrm{mol} \%)$

Relative yield $(-)=\frac{\text { Measured CPME yield }(\mathrm{mol} \%)}{\text { Initial CPME yield }(\mathrm{mol} \%)}$

The main by-product was CPE dimer generated by dimerization of CPE catalyzed by the acid catalyst.

\section{2. Analysis of Tar on the Catalyst}

Tar on the deactivated catalyst was dissolved with cyclopentane (CPA). The tar solution was concentrated using a rotary evaporator and analyzed by pyrolysis gas chromatography-mass spectrometry (GC-MS) analysis using a GC-MS system (6890 GC / 5973 N MSD, Agilent Technologies) together with a thermal decomposition unit (PY-2020 iD, Frontier Laboratories Ltd.).

\section{3. Experiment to Reproduce Tar Deposition on Deactivated Catalyst}

To reproduce tar formation on the deactivated catalyst, feedstocks were reacted with various phases. The strongly acidic ion exchange resin catalyst (RCP-160 M, Mitsubishi Chemical Corp.) and a fixed bed continuous flow type reaction system were used. The schematic illustration of the reactor is shown in Fig. 2, and the reaction conditions are listed in Table $\mathbf{3}$.

\section{4. Observation of Catalyst Bed in Accelerated} Deactivation Test

Direct observation of the change of catalyst bed during the accelerated deactivation test of the catalyst was carried out using the reactor shown in Fig. 3, under the conditions summarized in Table 4.

A glass double tube was employed as the reactor to visualize the inside of the reaction tube and $\mathrm{NaCl}$ aque-

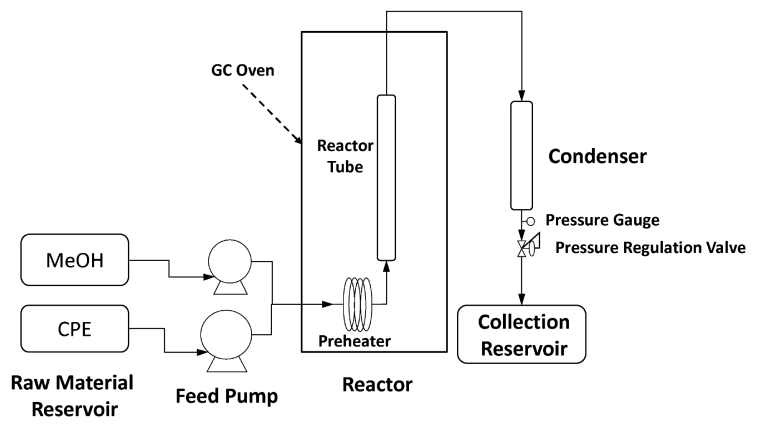

Fig. 2 Schematic Drawing of Reactor to Reproduce the Tar Observed in Life Test

Table 3 Reaction Conditions of Tar Reproduction Test

\begin{tabular}{lc}
\hline Feed content & $\mathrm{CPE} / \mathrm{MeOH}=1 / 0.63$ by mol \\
& $(\mathrm{CPE} / \mathrm{MeOH}=1 / 0.30 \mathrm{by} \mathrm{wt})$ \\
Bed length (dry base) & $180 \mathrm{~mm}$ \\
Tube inner diameter & $21.4 \mathrm{~mm}$ \\
LHSV & $0.65 \mathrm{~h}^{-1}$ \\
Outlet pressure & $0.0-0.3 \mathrm{MPaG}$ \\
HTF temperature & $40-90^{\circ} \mathrm{C}$ \\
\hline
\end{tabular}

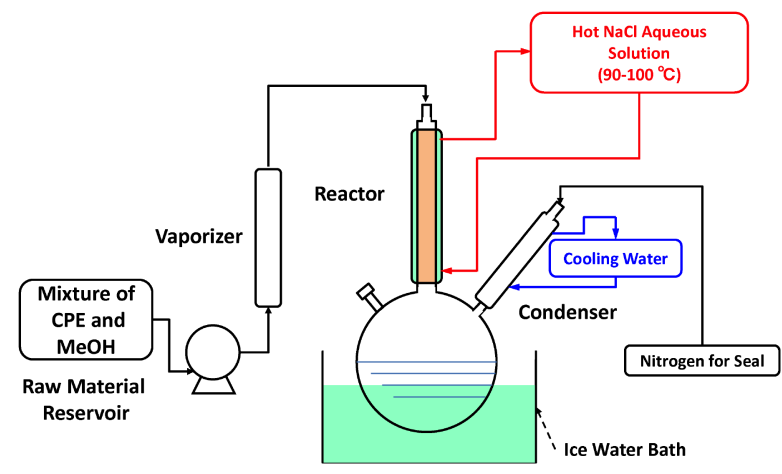

Fig. 3 Schematic Drawing of Lab Scale Reactor for Accelerated Life Test

Table 4 Reaction Conditions of Accelerated Life Test Using Lab Scale Reactor

\begin{tabular}{lc} 
Feed content & $\begin{array}{c}\mathrm{CPE} / \mathrm{MeOH}=1 / 0.63 \text { by mol } \\
(\mathrm{CPE} / \mathrm{MeOH}=1 / 0.30 \text { by wt })\end{array}$ \\
Bed length (dry base) & $210 \mathrm{~mm}$ \\
Tube inner diameter & $12.3 \mathrm{~mm}$ \\
GHSV & $400 \mathrm{~h}^{-1}$ \\
Outlet pressure & $0.0 \mathrm{MPaG}$ \\
HTF temperature & $90{ }^{\circ} \mathrm{C}$ \\
\hline
\end{tabular}

ous solution was used as the heating medium to prevent boiling. In addition, a small amount of the reaction solution was periodically collected, and the effluent flow rate was measured. The amount of the reactant per unit time was simultaneously measured, and the mass balance was calculated. The reaction solution was analyzed by gas chromatography and the parameters related to catalyst performance were calculated 
Table 5 Operation Conditions for C5 Diolefins Removal from CPE

\begin{tabular}{lc}
\hline Bed length & $400 \mathrm{~mm}$ \\
Tube inner diameter & $22.2 \mathrm{~mm}$ \\
LHSV & $2.9 \mathrm{~h}^{-1}$ \\
Outlet pressure & $0.1 \mathrm{MPaG}$ \\
Operation temperature & $40{ }^{\circ} \mathrm{C}$ \\
\hline
\end{tabular}

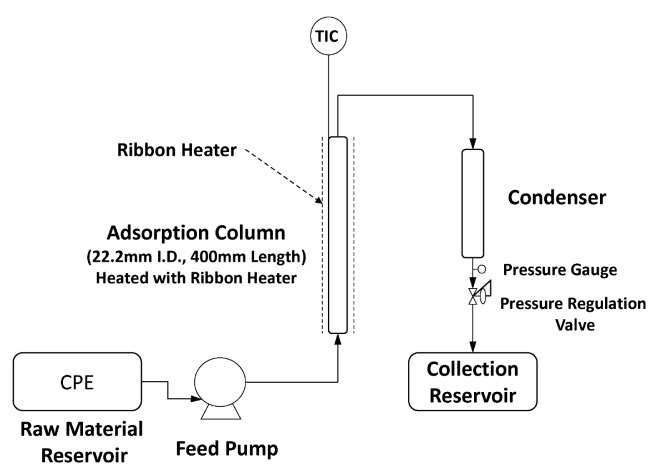

Fig. 4 Schematic Drawing of Treatment System for C5 Diolefins Removal from CPE

using Eqs. (1) to (6) as above. In addition, since the $\mathrm{CPA}$ contained in the raw material is inert to the reaction, the CPA content in the CPE was used as an internal standard to estimate the content of C5 diolefins. To calculate C5 diolefin leakage, the following calculation formula was applied;

$$
\begin{aligned}
& \text { Diolefins leakage }(\mathrm{mol} \%)= \\
& \frac{\text { Outlet flow of diolefins }(\mathrm{mol} / \mathrm{min})}{\text { Diolefins feed rate }(\mathrm{mol} / \mathrm{min})} \times 100
\end{aligned}
$$

\section{5. Removal of C5 Diolefins from CPE}

The raw material CPE contains trace amounts of $\mathrm{C} 5$ diolefins. Removal of C5 diolefins from CPE was carried out by the adsorption method as described ${ }^{22)}$ to investigate the effect of C5 diolefins on catalyst deactivation. Activated clay (Mizusawa Industrial Chemicals, Ltd., Galeonite No. 212, $1 \mathrm{~mm} \phi$ extrude) was used as adsorbent, in a fixed bed continuous method. The operating conditions are listed in Table $\mathbf{5}$, and the schematic flow of the removing device is shown in Fig. 4.

The raw material CPE was pumped and sent to an adsorption tube heated at $40{ }^{\circ} \mathrm{C}$. The effluent from the adsorption tube was condensed and collected in a reservoir. The concentration of diolefins in the purified CPE was measured by gas chromatography.

\section{Results and Discussion}

\section{1. First Catalyst Life Test}

Use of the ion exchange resin as a catalyst for the addition reaction of $\mathrm{CPE}$ and $\mathrm{MeOH}$ in a commercial process depends on the stability of the catalyst performance over extended operation. Therefore, the first

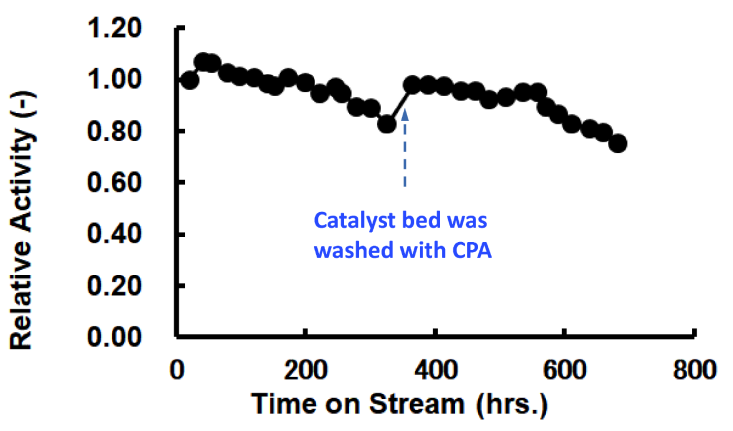

Fig. 5 Change in Relative Catalytic Activity (relative conversion of CPE) in the First Life Test

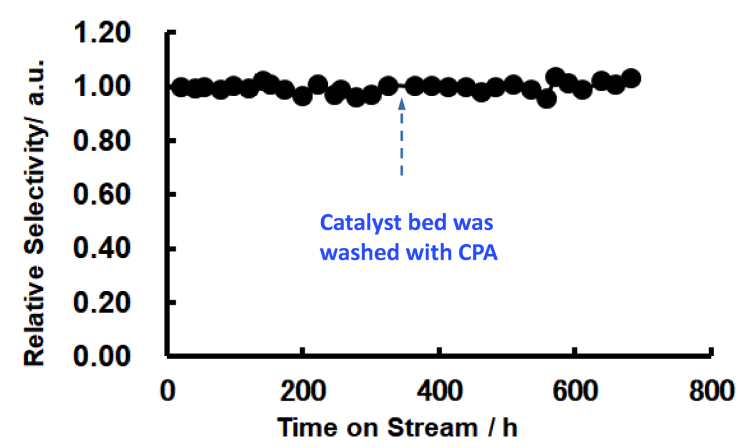

Fig. 6 Change in Relative Selectivity of CPME to CPE in the First Life Test

catalyst life test was conducted using the relative activity and relative selectivity described in section 2.1 . as performance parameters of the catalyst. Reaction conditions are listed in Table 2. Changes in relative activity and relative selectivity over time are shown in Figs. 5 and 6, respectively.

Relative selectivity showed no significant decrease, whereas relative activity decreased with time. Relative activity recovered at $380 \mathrm{~h}$, when the catalyst layer was washed with CPA, but decreased with time. After completion of the test, the reaction tube was opened, and the catalyst was sequentially withdrawn. Catalyst near the inlet of the reaction tube was blackened and hardened. In addition, viscous deposits had adhered to the catalyst surface in the vicinity of the center of the catalyst bed. Only about $1 / 4$ of the length in the vicinity of the outlet had maintained the same state as the initial stage of the reaction. Washing of the colored spent catalyst with CPA obtained blackish brown liquid, and the color of the catalyst became less intense. Clearly, the catalyst deposits were dissolved in CPA. Dissolution of the deposit on the spent catalyst and recovery of the catalytic activity by washing with CPA in the middle of the life test suggested that the tar recovered by catalyst washing was a catalyst poison. Therefore, the obtained blackish brown solution was concentrated, and the obtained tar was analyzed as described in section 2. 2. Trace amount of CPE dimer 


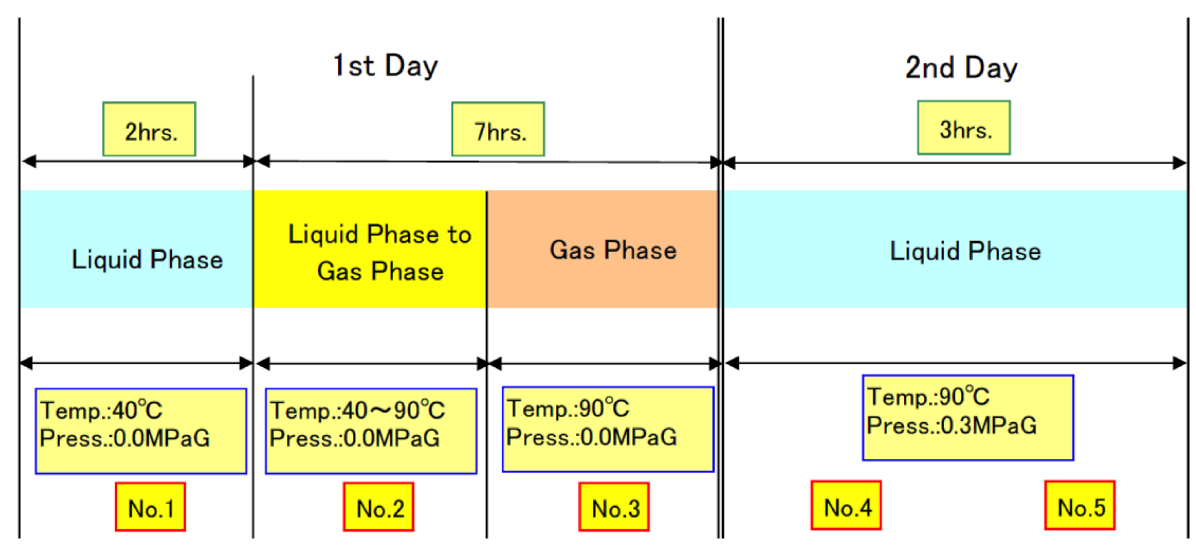

Fig. 7 Time Table for Changing Operation Conditions in the Tar Reproduction Test

was detected, but a large number of components with high boiling points were also detected, which were not completely decomposed under the present conditions. These components could not be effectively separated by gas chromatography, and so the molecular weight was impossible to measure by MASS.

Examination of the time course of the reaction in the life test suggests that the number of effective active sites on the catalyst decreased with time, since the relative selectivity was constant, whereas the relative activity decreased. This loss of catalytic activity was probably caused by poisoning of the active sites by the tar soluble in CPA. The CPE used as feedstock contained about $0.03 \%$ of C5 diolefins (cyclopentadiene, 1,3-pentadiene, etc.), but these C5 diolefins are not detected from the reaction solution in the life test even at the end. Since all C5 diolefins are conjugated dienes and likely to undergo polymerization, the origin of the tar formation was presumed to be the presence of C5 diolefins.

\section{2. Study of Tar Generation}

The cause of the catalyst deactivation was regarded as the formation of tar, which was found to be soluble in CPA. Reproduction of tar generation was carried out by the method described in section 2. 3. to clarify whether the tar was generated by gas phase or liquid phase reaction. The causative substance of the tar generation was presumed to be $\mathrm{C} 5$ diolefins, so the concentration of C5 diolefins in CPE feedstock was increased to $1.1 \mathrm{GC} \%$ by adding more diolefins to promote tar generation. The experiments were conducted at increasing temperature and pressure. The schematic procedure of the experimental conditions is shown in Fig. 7.

The experiment was conducted over 2 days. The temperature of the catalyst bed was lowered to room temperature at the end of the 1st day, and the catalyst bed was replaced with nitrogen. Then, the inlet and the outlet of the reaction tube were sealed. At the restart of the experiment on the second day, the temperature was raised with nitrogen circulated in the system.
When the temperature reached a predetermined temperature, the nitrogen flow was stopped, and flow of the feedstock was started. The presence or absence of tar formation was confirmed by the presence or absence of coloring of the reaction effluent. If tar was produced under low-temperature $\left(40^{\circ} \mathrm{C}\right)$ liquid phase operation (conditions No. 1 to No. 2), it was dissolved in unreacted CPE with polarity and structure similar to CPA, and removed from the reactor outlet. Consequently, the reaction effluent became colored. On the other hand, if tar was generated under the high-temperature $\left(90{ }^{\circ} \mathrm{C}\right)$ liquid phase operation (conditions No. 4 to No. 5), the reaction liquid was uniformly colored. Vapor pressure of $\mathrm{CPE}$ at $90{ }^{\circ} \mathrm{C}$ is $0.37 \mathrm{MPa}$ abs. and vapor pressure of $\mathrm{MeOH}$ at the same temperature is $0.26 \mathrm{MPa}$ abs. Therefore, both $\mathrm{CPE}$ and $\mathrm{MeOH}$ remained in the liquid phase under the No. 4 and No. 5 conditions $\left(90^{\circ} \mathrm{C}\right.$, $0.30 \mathrm{MPaG}=0.403 \mathrm{MPa}$ abs.). If tar is generated only in the gas phase reaction region (conditions No. 3) at high temperature, the reaction effluent under condition No. 4 should be markedly colored. Furthermore, the reaction solution from condition No. 5 should not be colored. These experiments found that only the effluent of the No. 4 operation was clearly colored. Therefore, the tar was generated by gas phase reaction. The reaction solution recovered under conditions No. 4 was concentrated and subjected to pyrolysis GC-MS measurement as described in section 2. 2. The analysis almost agreed with the analysis of tar performed in section 3.1 . Therefore, the tar causing the catalyst poisoning was generated by gas phase reaction.

\section{3. Tar Generation and Reduction of Catalyst Activity}

Clearly, the tar causing the catalyst poisoning was generated by gas phase reaction. However, the correlation between the amount of tar produced and catalyst deactivation was unclear. Therefore, the reaction was carried out according to the method described in section 2. 4., in which the coloring rate of the catalyst bed was visually measured. Catalyst activity and diolefin leak- 
age were simultaneously measured, and the correlation between tar formation and catalyst deactivation was examined. The concentration of C5 diolefins in CPE was adjusted to $2.6 \%$. Figure 8 shows the change in the length of colored catalyst bed with time on stream. In addition, the time course of the diolefin leakage with change of CPME relative yield is shown in Fig. 9.

The length of the colored area of the catalyst bed increased linearly with time on stream (Fig. 8). On the other hand, the relative yield slowly decreased with time on stream, whereas the diolefin leakage increased (Fig. 9), until the operation time reached $21 \mathrm{~h}$, when $86 \%$ of the catalyst bed was colored. These observations suggest that polymerization of $\mathrm{C} 5$ diolefins proceeded rapidly on the ion exchange resin because of its strong acid cites. The polymerization reaction generating tar poisoned the active cites. Finally, after the

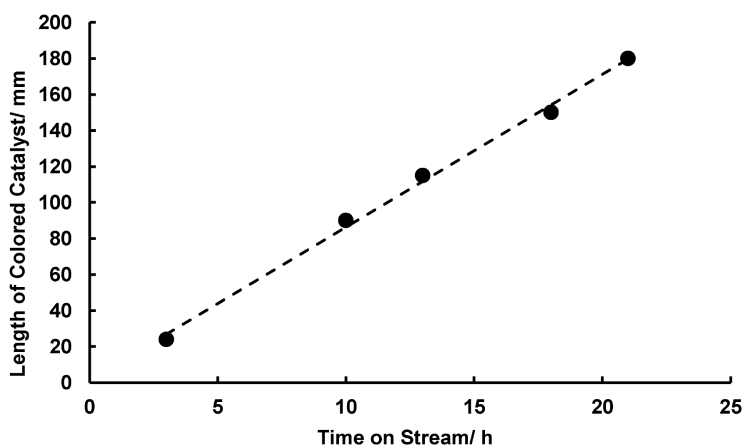

Fig. 8 Change in the Length of Colored Catalyst Bed in the Accelerated Life Test whole catalyst bed was completely colored, the polymerization rate of $\mathrm{C} 5$ diolefins sharply declined, and unreacted $\mathrm{C} 5$ diolefins leaked from the reaction tube outlet. A schematic drawing of the catalyst deactivation mechanism is shown in Fig. 10.

Cationic polymerization of diolefin proceeds even in the presence of Brønsted acid ${ }^{23), 24)}$. However, if polymerization progresses and the catalyst surface is completely covered with $\mathrm{C} 5$ diolefins polymer, both the reaction substrate $(\mathrm{CPE})$ and the reactant $(\mathrm{MeOH})$ cannot reach the acidic active sites on the catalyst surface, resulting in hindrance of the main reaction. Since C5 diolefin has a conjugate structure, the intermediate for the C5 diolefin polymerization reaction is relatively stable. Therefore, C5 diolefin is probably polymerized on the catalyst surface. Furthermore, if C5 diolefins are

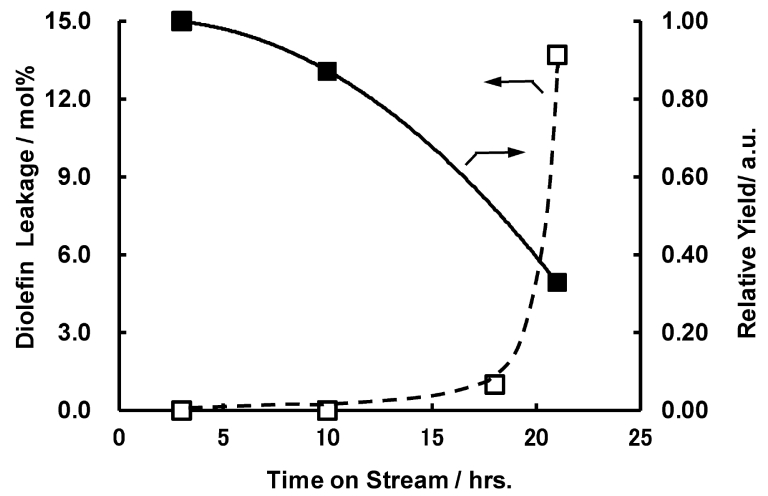

Fig. 9 Change in Relative Yield (solid line) and C5 Diolefins Leakage (broken line) in the Accelerated Life Test

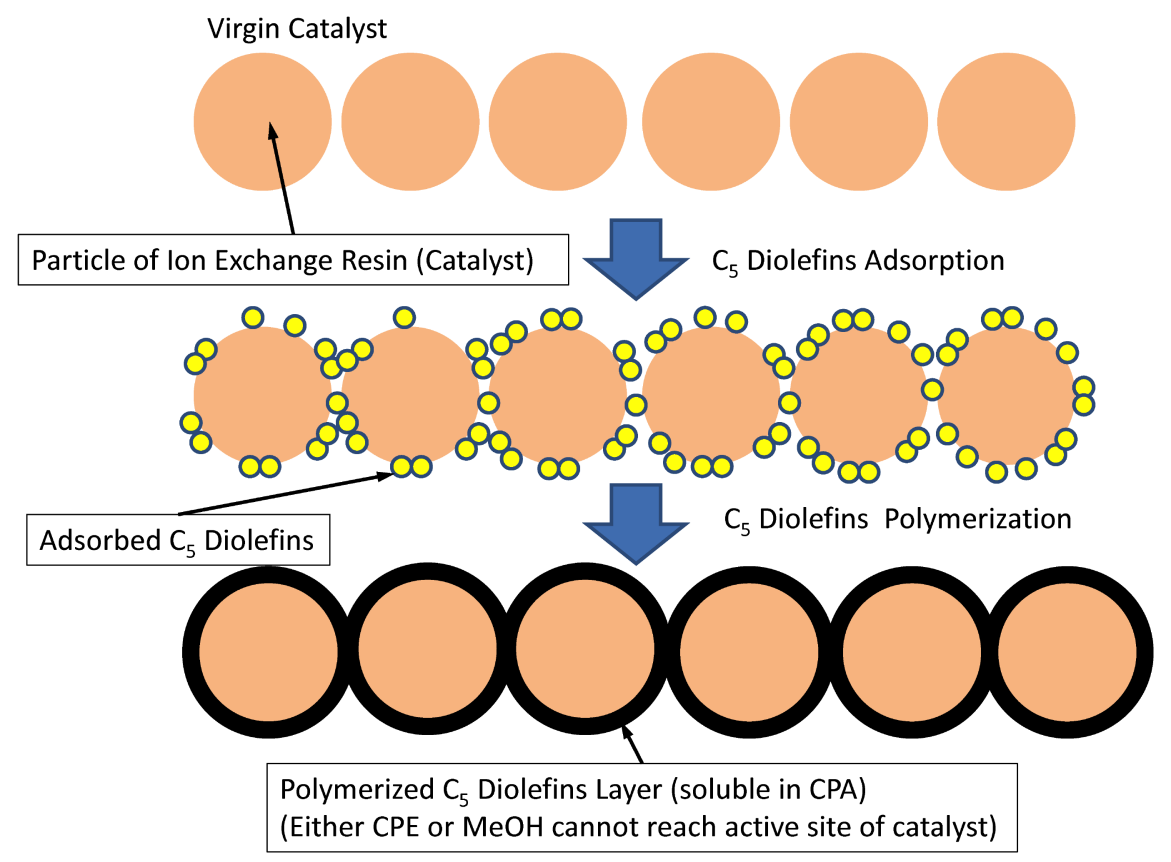

Fig. 10 Schematic Drawing of Catalyst Deactivation Mechanism with C5 Diolefins Polymerization 


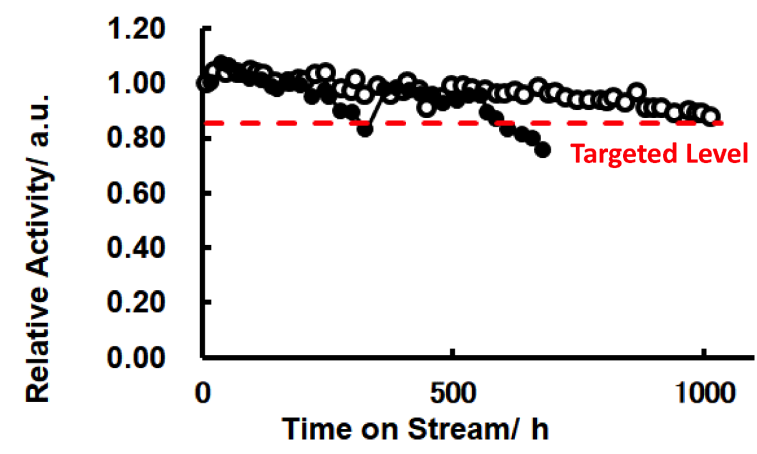

Filled and open circles show the first and second trials, respectively.

Fig. 11 Relative Catalytic Activity in the First and Second Life Tests

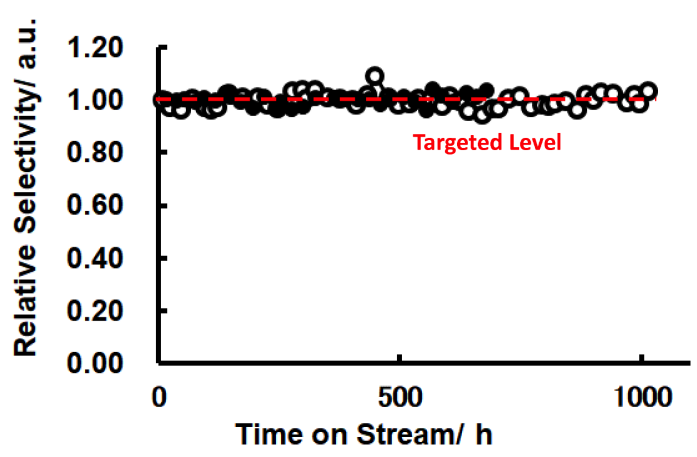

Filled and open circles show the first and second trials, respectively.

Fig. 12 Relative Selectivity in the First and Second Life Tests

polymerized at the acid sites on the catalyst surface, the acid active sites for the main step of addition of $\mathrm{MeOH}$ to CPE would be poisoned selectively. The present findings show that $\mathrm{C} 5$ diolefin polymerization is the main factor in the poisoning of the active sites and deactivation of the catalyst.

\section{4. Second Catalyst Life Test}

Clearly, the C5 diolefins are the origin of the catalyst poisoning substances. Therefore, CPE containing no C5 diolefins was prepared by the method described in section 2. 5., and the second life test of the catalyst was conducted using the purified feedstock. The concentration of C5 diolefins was below the detection limit. The change in relative activity is shown in Fig. 11, and the change in relative selectivity in Fig. 12, together with the result of the first life test.

Reduction of the catalytic activity was suppressed by removing the $\mathrm{C} 5$ diolefins from the raw material $\mathrm{CPE}$ as shown in Fig. 11. In addition, selectivity remained constant during operation over $1000 \mathrm{~h}$, and no significant decrease occurred as shown in Fig. 12. These results support the assumption that the catalyst surface is covered with C5 olefin polymer, and that the catalytic activity declines due to the polymerization of C5 diole- fins on the catalyst.

\section{Conclusion}

The change in catalyst activity for gas phase continuous addition reaction using strongly acidic ion exchange resin was investigated by various methods. The first catalyst life test showed that tar soluble in CPA adheres to the catalyst. Studies of tar formation under various reaction temperature and pressure conditions clarified the involvement of gas phase reaction. The second life test was conducted using CPE containing no C5 diolefins as feedstock, and the reduction in catalyst activity was greatly suppressed with high selectivity maintained for $1000 \mathrm{~h}$. Therefore, polymerization of C5 diolefins to form tar on the active sites caused the reduction in the catalytic activity.

\section{Acknowledgment}

H. M. would like to express heartfelt thanks to Dr. N. Kogoshi for his dedication to many experiments to clarify the mechanism of the catalyst deactivation. H. M. would also like to express much gratitude to Ms. Misako Asada, leader of the analytical team, basic technology laboratory of Research \& Development Center, Zeon Corporation, who gave me dedicated assistance in various analyses to advance this research. H. M. would also like to thank Prof. Y. Sakata of Yamaguchi University and Prof. J. N. Kondo of Tokyo Institute of Technology for their advice on consolidating this paper.

\section{References}

1) Kirk-Othmer, "Concise Encyclopedia of Chemical Technology," Vol. 1, Wiley-Interscience, (2007), p. 969.

2) Wessermel, K., Arpe, H.-J., Mukaiyama, T., (transcription), "Industrial Organic Chemistry," Tokyo Kagaku Doujin, (2004), p. 107.

3) "Zeon Corp. Technical Data Book of Cyclopentyl Methyl Ether," p. 2.

4) Kimmer, K. L., Robak, M. T., Ellman, J. A., J. Am. Chem. Soc., 131, (25), 8754 (2009).

5) Saito, N., Yamazaki, T., Sito, Y., Chem. Lett., 38, (6), 594 (2009).

6) Fei, Z., Wu, Q., Zhang, F., Cao, Y., Liu, C., Shieh, W., Xue, S., McKenna, J., Prasad, K., Prasha, M., Baeschlin, D., Namoto, K., J. Org. Chem., 73, 9016 (2010).

7) Hayashi, M., Nakamura, S., Angew. Chem. Int. Ed., 50, 2249 (2011).

8) Shimada, T., Suda, M., Nagano, T., Kakiuchi, K., J. Org. Chem., 70, 10178 (2005).

9) Tanaka, Y., Mino, T., Akita, K., Sakamoto, M., Fujita, T., J. Org. Chem., 69, 6679 (2004).

10) Yamamoto, T., Abe, M., Takahashi, Y., Kawata, K., Kubota, K., Polymer J., 35, (7), 603 (2003).

11) Miki, H., PETROTECH, 41, (9), 700 (2018).

12) Fukuda, J., J. Ion Exchange, 15, (1), 30 (2004).

13) Kusano, H., PETROTECH, 10, (12), 1075 (1987).

14) Nippon Oil Co., Ltd., Jpn. Kokai Tokkyo Koho JP1979-59209 (1979). 
15) Nippon Oil Co., Ltd., Jpn. Kokai Tokkyo Koho JP1980-118431 (1980).

16) Tonen Corp., Jpn. Kokai Tokkyo Koho JP1981-5424 (1981).

17) Nippon Shokubai Co., Ltd., Jpn. Kokai Tokkyo Koho JP1983192851 (1983).

18) Nippon Kayaku Co., Ltd., Jpn. Kokai Tokkyo Koho JP1980122740 (1980).

19) Phillips Petroleum, Jpn. Kokai Tokkyo Koho JP1983-26833 (1983).
20) Murakami, Y., Hattori, T., Uchida, H., Kogyo Kagaku Zasshi, 72, (9), 1949 (1969).

21) Zeon Corp., Jpn. Kokai Tokkyo Koho JP2006-206536 (2006).

22) Maruzen Petrochemical Co., Ltd., Jpn. Kokai Tokkyo Koho JP2003-137821 (2003).

23) Higashimura, T., Sawamoto, M., Adv. Polym. Sci., 62, 49 (1984).

24) Faust, R., Kennedy, J. P., Polym. Bull., 15, 317 (1986).

要旨

強酸性イオン交換樹脂を触媒とした気相接触反応によるシクロペンチルメチルエーテルの合成

一触媒活性低下要因の解明一

\author{
三木 英了 \\ 日本ゼオン(株)総合開発センター，210-9507川崎市川崎区夜光1-2-1
}

強酸性イオン交換樹脂を触媒としたシクロペンテンとメ夕 ノールの連続気相付加反応によるシクロペンチルメチルエーテ ルの製造法開発を目的として, 触媒寿命に関する検討を行った ところ, 触媒活性が経時的に低下することが明らかになった。 使用済み触媒に堆積した物質の解析, 反応前後の微量不純物の 挙動の解析等により, C5 ジオレフィンが劣化要因物質である
ことが示唆された。そこで, C5 ジオレフィンを除去した原料 を用いた寿命試験を行ったところ, 触媒活性低下が大幅に抑制 された。ここでは, 堆積物 (タール) 生成の再現実験, 反応管 内部を可視化した反応器による加速劣化実験等の結果から, 触 媒劣化のメカニズムについて考察した。 